\title{
MLL/LPP Fusion Gene
}

National Cancer Institute

\section{Source}

National Cancer Institute. MLL/LPP Fusion Gene. NCI Thesaurus. Code C99329.

A fusion gene that results from a chromosomal translocation $t(3 ; 11)(q 28 ; q 23)$ which fuses exon 8 of the MLL gene to exon 9 of the LPP gene. This rearrangement is associated with treatment-related acute myeloid leukemia. 